\title{
Hemp Fertilization: Current Knowledge, Gaps and Efforts in Florida: A 2020 Report $^{1}$
}

\author{
Rao Mylavarapu, Zachary Brym, Luis Monserrate, and Michael J. Mulvaney²
}

\section{Introduction}

Starting the last week of April 2020, the Florida Department of Agriculture and Consumer Services began accepting applications for cultivation of hemp (Cannabis sativa; Figure 1 ) in Florida, with the potential for building a $\$ 20-\$ 30$ billion industry in the state.

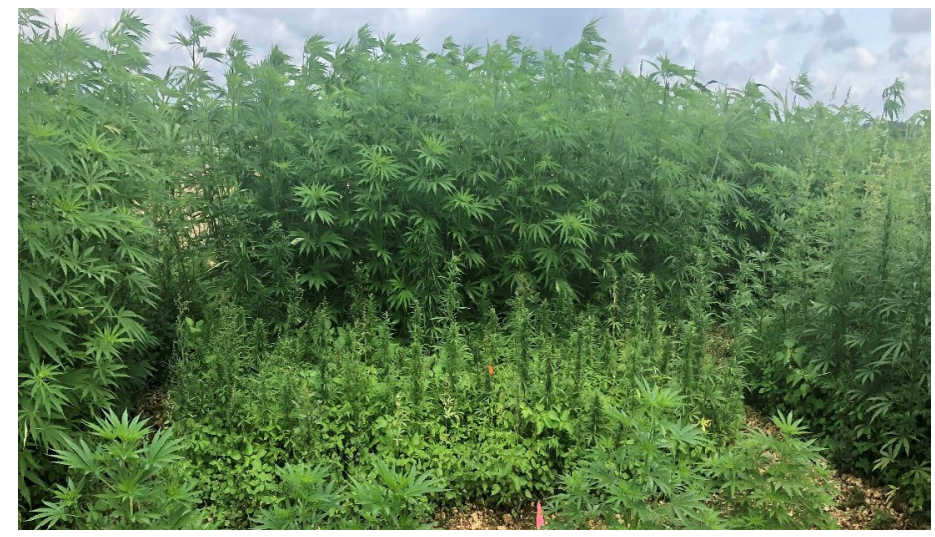

Figure 1. Hemp (Cannabis sativa) cultivation in Florida. Credits: Luis Monserrate, graduate student, UF/IFAS Agronomy Department

\section{Hemp Usages and Production Systems}

Hemp is an annual herbaceous plant that may be grown for fiber, seed, or flowers. However, it is not a cover crop like sunn hemp (a legume, Crotalaria juncea; Figure 2) and is also different from jute (a fiber crop, Corchorus olitorius; Figure 3). Hemp is classified as a noxious weed in several states and is predicted by the UF/IFAS Assessment of Non-native Plants in Florida's Natural Areas to have a high invasion risk in Florida. Hemp is predominantly a shortday plant, and the reproductive phase will begin only when the day length is less than 11 to 14 hours of sunlight. Hemp grown for seed is generally grown with medium to shorter varieties. Hemp varieties grown for flowers range in height with relatively wide canopies and are grown primarily to extract essential oils, the quantity of which increases when flowers are not pollinated. In the United States, because few herbicides are labeled for hemp at this time, either field layouts with sufficient spacing for open-field cultivation or cultivation under plastic mulch is preferred to combat weeds. Direct seeding into the ground is preferred for fiber and seed production at a very high plant density (0.1-0.8 million/acre) to encourage shoot growth or seed production in view of its lower economic value. However, for flowers (total delta-9 THC $<0.3 \%$ ), planting on raised beds is recommended at lower plant density $(<10,000 /$ acre) for high flowering without pollination because of higher economic value. Well-drained soils are preferred for hemp cultivation and require adequate moisture at planting for optimum establishment. Extended periods of flooding should be avoided. Approximately $1 / 2$ to 2 inches of irrigation is recommended per week, and fertigation is a preferred method when grown on plastic-mulched beds.

1. This document is SL476, one of a series of the Department of Soil and Water Sciences, UF/IFAS Extension. Original publication date August 2020. Visit the EDIS website at https://edis.ifas.ufl.edu for the currently supported version of this publication.

2. Rao Mylavarapu, professor and director, UF/IFAS ANSERV Labs, Department of Soil and Water Sciences; Zachary Brym, assistant professor, agroecology; Luis Monserrate, graduate research assistant, Agronomy Department, UF/IFAS Tropical Research and Education Center; and Michael J. Mulvaney, assistant professor and cropping systems specialist, Agronomy Department, UF/IFAS West Florida REC_Milton; UF/IFAS Extension, Gainesville, FL 32611

The Institute of Food and Agricultural Sciences (IFAS) is an Equal Opportunity Institution authorized to provide research, educational information and other services

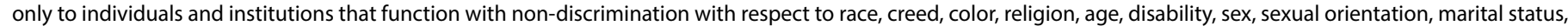

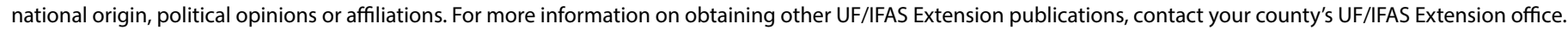
U.S. Department of Agriculture, UF/IFAS Extension Service, University of Florida, IFAS, Florida A \& M University Cooperative Extension Program, and Boards of County Commissioners Cooperating. Nick T. Place, dean for UF/IFAS Extension. 


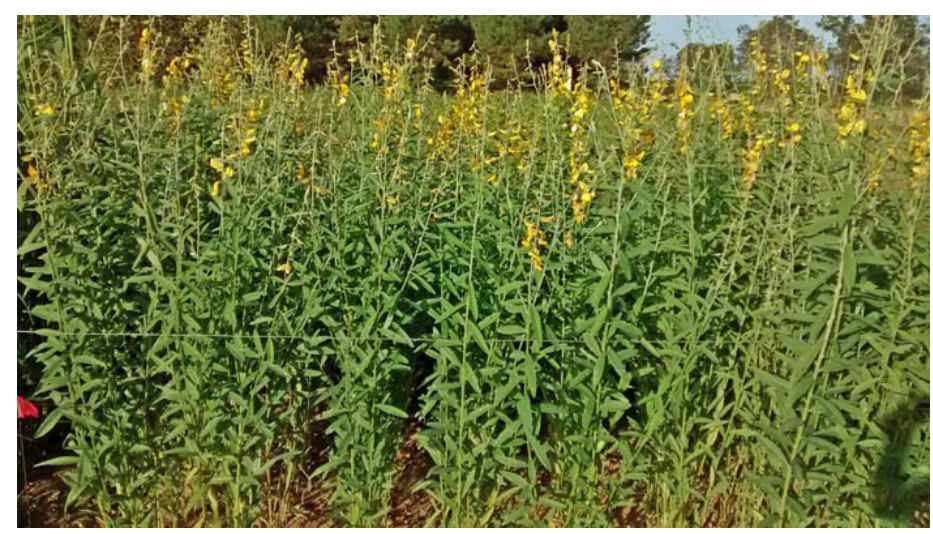

Figure 2. Sunn hemp (Crotalaria juncea) grown as cover crop. Credits: Arun Jani, graduate student, UF/IFAS Agronomy Department

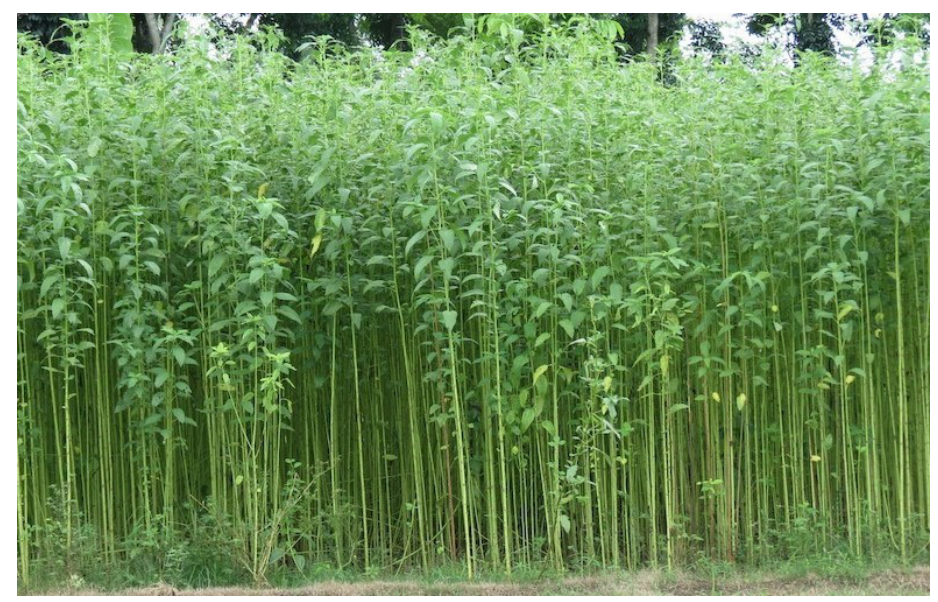

Figure 3. Jute (Corchorus olitorius) cultivation for fiber.

Credits: Malcolm Manners, Wikimedia Commons. Licensed under the Creative Commons Attribution 2.0 Generic license.

The statewide UF/IFAS Industrial Hemp Pilot Project is researching aspects of agronomic production for hemp cultivation. While a few other state soil testing laboratories, such as those at Penn State, University of Kentucky, and the North Carolina Department of Agriculture, provide soil tests and nutrient recommendations based on research and experience, at this time no Florida-specific data on nutrient requirements and fertilization are available.

This article provides a summary of published and personal communications from different states on hemp fertilization.

\section{Nutrient Requirements of Hemp}

Currently, limited soil fertility research is available to determine accurate nutrient requirements of hemp, interpretation of soil test data, and recommendations for applications across the United States. Soil test recommendations for agronomic row crops such as corn (Zea mays L.) or small grains may be considered adequate in certain cases for grain or fiber hemp production as a starting point. However, research done outside the United States provides some insights on hemp nutrition. Current studies in Canada showed that the total plant uptake was $224 \mathrm{lb} \mathrm{N} /$ acre, $53 \mathrm{lb} \mathrm{P}_{2} \mathrm{O}_{5} /$ acre, and $236 \mathrm{lb} \mathrm{K} 2 \mathrm{O} /$ acre. Grain removal accounted for $45 \mathrm{lb} \mathrm{N} /$ acre, $21 \mathrm{lb}_{2} \mathrm{O}_{5} /$ acre, and $11 \mathrm{lb} \mathrm{K} \mathrm{O} /$ acre (Heard et al. 2007). Other studies conducted in Italy and China generally agreed with such levels of nutrient uptake (Angelini et al. 2014; Deng et al. 2019).

\section{Guidance for Florida}

Currently available information within the region and outside suggests that the data are similar to $\mathrm{P}$ and $\mathrm{K}$ recommendations for nonirrigated corn production in Florida. Research in Canada and Europe found limited response to additions of $\mathrm{P}$ and $\mathrm{K}$ for fiber and grain hemp, but likely the lack of response was due to high initial soil test levels (Vera et al. 2010; Finnan \& Burke 2013; Angelini et al. 2014; Aubin et al. 2015). Recommendations for $\mathrm{P}$ and $\mathrm{K}$ nonirrigated corn in Florida (Mylavarapu et al. 2015: SL129, UF/IFAS Standardized Fertilization Recommendations for Agronomic Crops) based on Mehlich-3 soil extraction are shown in Table 1.

Table 1. UF/IFAS Recommendations for $\mathrm{P}_{2} \mathrm{O}_{5}$ and $\mathrm{K}_{2} \mathrm{O}$ for nonirrigated grain corn based on Mehlich-3 soil test levels.

\begin{tabular}{|l|c|c|c|}
\hline \multicolumn{1}{|c|}{$\begin{array}{c}\text { Nutrient } \\
\text { Recommendations }\end{array}$} & \multicolumn{3}{|c|}{ Soil Test Levels } \\
\hline & High & Medium & Low \\
\hline $\mathrm{P}_{2} \mathrm{O}_{5}$ (lb/acre) & 0 & 50 & 125 \\
\hline $\mathrm{K}_{2} \mathrm{O}$ (lb/acre) & 0 & 60 & 120 \\
\hline
\end{tabular}

Because soil test correlation and calibration data are not available for Florida, the above $\mathrm{P}$ and $\mathrm{K}$ rates serve as guidance for hemp production based on the regional data until such time as Florida-specific research can be conducted.

The $\mathrm{N}$ applications should not exceed $150 \mathrm{lb}$ N/acre, similar to the data found in the region. The $\mathrm{N}$ recommendation is based on research data on the crop requirement and not on a soil test. The $\mathrm{N}$ requirement for hemp varies with the purpose of cultivation. Seed and flower may require $\mathrm{N}$ rates of up to about $200 \mathrm{lb}$ per acre (Struik et al. 2000; Vera et al. 2010; Angelini et al. 2014; Aubin et al. 2015; Deng et al. 2019), whereas when grown for fiber, $50 \mathrm{lb}$ N/acre may be adequate, because too much $\mathrm{N}$ can reduce fiber quality.

$\mathrm{N}$ application should preferably be applied in 2-3 split applications to enhance uptake and minimize leaching in sandy soils. Typical proportion of split applications is $30 \mathrm{lb}$ $\mathrm{N} /$ acre at planting and the rest approximately 3 weeks after planting. Continued monitoring of soil and plant tissue for $\mathrm{N}$ levels is important, specifically using plant tissue tests for determining sufficiency throughout the season and paying 
attention to chlorosis of lower leaves. Published values on tissue nutrient levels are shown in Table 2, which may serve just as a reference point.

Table 2. Hemp leaf tissue survey ranges based on 15 mature leaves from new growth during vegetative growth in a production nursery. Data from Bryson \& Mills (2014).

\begin{tabular}{|c|c|c|c|}
\hline \multicolumn{2}{|c|}{ Macronutrients (\%) } & \multicolumn{2}{c|}{ Micronutrients (ppm) } \\
\hline $\mathrm{N}$ & $3.80-4.80$ & $\mathrm{Fe}$ & $100-150$ \\
\hline $\mathrm{P}$ & $0.19-0.25$ & $\mathrm{Mn}$ & $41-93$ \\
\hline $\mathrm{K}$ & $1.80-2.00$ & $\mathrm{~B}$ & $56-105$ \\
\hline $\mathrm{Ca}$ & $0.40-0.60$ & $\mathrm{Cu}$ & $5.0-7.1$ \\
\hline $\mathrm{Mg}$ & $0.15-0.30$ & $\mathrm{Zn}$ & $24-52$ \\
\hline $\mathrm{S}$ & $0.10-0.30$ & Mo & $0.5-1.5$ \\
\hline
\end{tabular}

Hemp is found to grow well between a soil $\mathrm{pH}$ range of 6.0 to 7.0. However, it was found to grow even at soil $\mathrm{pH}$ values above 7.0 in calcareous soils of Florida. To ensure optimum nutrient supply on acid-mineral soils of Florida, the suggested $\mathrm{pH}$ is 6.5 .

The data provided on the UF/IFAS soil test report will consist of the following:

Extractable nutrient levels in the soil, including phosphorus $(\mathrm{P})$, potassium $(\mathrm{K})$, sulfur $(\mathrm{S})$, calcium $(\mathrm{Ca})$, magnesium $(\mathrm{Mg})$, copper $(\mathrm{Cu})$, zinc $(\mathrm{Zn})$, and manganese $(\mathrm{Mn})$, and guidelines for nutrient applications, as appropriate, based on the purpose of cultivation, namely fiber, seed or flowers, and based on the plant densities described previously.

\section{Soil Testing at the UF/IFAS Extension Soil Testing Laboratory (ESTL)}

Soil samples should be submitted for hemp cultivation 4-6 weeks prior to planting. The Extension Soil Testing Lab will use the specific crop code \#15 for hemp sample submissions. The standard soil fertility test will provide information on soil $\mathrm{pH}$, lime requirement (only when necessary), N, Mehlich-3 extractable P, K, Ca, Mg, S, Cu, Mn, and Zn. An effective nutrient management program for optimal production should couple the information obtained from soil and plant tissue analyses and be considered along with various influencing factors such as weather and soil type (Mylavarapu 2010).

Because access to Florida-specific information is not available to generate nutrient recommendations for optimal production, careful monitoring of plant and soil nutrient levels should be compared to available guidelines to estimate reasonable applications. Special consideration should be made not to overapply fertilizer, because nutrient loading of waterbodies is a critical issue for the region.

The above guidelines will be updated as and when research data from Florida become available. The following regional data contributed towards formulation of nutrient guidelines for hemp cultivation in Florida.

\section{Provisional Data from Regional Soil Test Labs}

- Dr. Frank Sikora, University of Kentucky (personal communication, June 2020):

While research work on hemp production has been initiated at the University of Kentucky, their interim guidelines are to fertilize for $\mathrm{P}$ and $\mathrm{K}$ as in wheat (Triticum aestivum L.) production for Kentucky. These guidelines are similar to the guidelines found elsewhere (Ontario Ministry of Agriculture 2017; Cherney and Small 2016).

The University of Kentucky (UKY) recommends a soil $\mathrm{pH}$ of 6.4 for all hemp production. This $\mathrm{pH}$ is very close to the recommendation for most agronomic and vegetable crops grown on sandy soils and will ensure optimum nutrient solubility and availability.

Based on soil tests using the standard Mehlich-3 soil extractant procedure, UKY recommends the following:

Phosphorus: 0-120 lb $\mathrm{P}_{2} \mathrm{O}_{5}$ /acre

Potassium: 0-80 lb $\mathrm{K}_{2} \mathrm{O} / \mathrm{acre}$

For nitrogen, UKY recommends:

$50 \mathrm{lb} \mathrm{N} / \mathrm{acre}$ for fiber production

$100-150 \mathrm{lb}$ N/acre for grain production

100-150 lb N/acre for CBD/flowers (preliminary data from field trials)

- Dr. John Spargo, Penn State (personal communication, June 2020):

Hemp is best adapted to well-drained soil with a $\mathrm{pH}$ between 6.0 and 7.0. Hemp does not grow well on wet soils or those with a heavy clay content. Hemp that is direct seeded is sensitive to soil crusting and soil compaction, which can occur on these soils. 
Using standard Mehlich-3 extraction-based soil tests, the Agricultural Analytical Services Lab at Penn State recommends:

$$
\begin{aligned}
& \text { P: 0-120 lb } \mathrm{P}_{2} \mathrm{O}_{5} / \text { acre } \\
& \text { K: 0-110 lb K } \mathrm{O} \text { /acre }
\end{aligned}
$$

For nitrogen, Penn State recommends: $150 \mathrm{lb}$ N/acre

- Drs. David Hardy and Michelle McGinnis, NC Department of Agriculture (personal communication, June 2020)

The target soil $\mathrm{pH}$ recommended for hemp production is 6.2 (for mineral soils) and 5.5 and 5.0 for mineral-organic and organic soils, respectively. Research on hemp production and nutrition has just started and so the current soil test guidelines are based on preliminary data available in the neighboring states, particularly Kentucky. The soil test lab at the NC Department of Agriculture accepts soil samples for hemp cultivation and provides the following recommendations (approximate amounts estimated using their indexing system and may vary by $+/-10 \mathrm{lb} / \mathrm{acre}$ ) based on Mehlich-3 extraction method for seed production:

$$
\begin{aligned}
& \text { P: 0-90 lb } \mathrm{P}_{2} \mathrm{O}_{5} / \text { acre } \\
& \text { K: 0-100 lb K } \mathrm{K} \text { /acre }
\end{aligned}
$$

For Nitrogen: 100-150 lb/acre is recommended for seed production.

Preliminary results suggest that the flowering response peaks in the range of 100-120 lb N/acre. Nitrogen should not be applied in-row. For seed production, split applications are suggested on sandy soils with 50 to $75 \mathrm{lb} \mathrm{N} / \mathrm{ac}$ at

\begin{tabular}{|c|c|c|c|c|}
\hline \multirow{2}{*}{$\begin{array}{l}\text { Nutrient } \\
\text { Rates }\end{array}$} & $\mathbf{P}_{2} \mathbf{O}_{5}$ & $\mathbf{K}_{2} \mathbf{O}$ & $\mathbf{N}$ & \multirow[t]{2}{*}{ Reference* } \\
\hline & \multicolumn{3}{|c|}{$\begin{array}{l}\text { Recommendation rates } \\
\text { (Ib/acre) }\end{array}$} & \\
\hline Penn State ${ }^{\#}$ & $0-120^{\#}$ & $0-110^{\#}$ & 150 & Dr. John Spargo \\
\hline UKY & $0-120$ & $0-80$ & 150 & Dr. Frank Sikora \\
\hline NC State & $0-90$ & $0-100$ & $\begin{array}{c}150 \\
\left(120^{* *}\right)\end{array}$ & $\begin{array}{l}\text { Drs. David Hardy \& } \\
\text { Michelle McGinnis }\end{array}$ \\
\hline Florida & $0-125$ & $0-120$ & 150 & $\begin{array}{l}\text { Dr. Mylavarapu et al. (this } \\
\text { document) }\end{array}$ \\
\hline \multicolumn{5}{|c|}{$\begin{array}{l}\text { *Based on regional experience } \\
\text { \# approx. values for } 1250 \mathrm{lb} / \text { acre yield goal } \\
\text { **based on preliminary research }\end{array}$} \\
\hline
\end{tabular}
planting with the remainder applied 30 days afterward.

Table 3. Summary of current regional soil test-based hemp nutrient recommendations.
The current available information and the proposed nutrient guidance for Florida is summarized in Table 3.

\section{References}

Angelini, L. G., S. Tavarini, B. Cestone, and C. Beni. 2014. "Variation in Mineral Composition in Three Different Plant Organs of Five Fibre Hemp (Cannabis sativa L.) Cultivars." Agrochimica 58 (1): 1-18.

Aubin, M., P. Sequin, A. Vanasse, G. Tremblay, A. F. Mustafa, and J.-B. Charron. 2015. "Industrial Hemp Response to Nitrogen, Phosphorus, and Potassium Fertilization." Crop, Forage, and Turfgrass Management 1 (1): 1-10. https://doi. org/10.2134/cftm2015.0159.

Bryson, G. M., and H. A. Mills. 2014. Plant Analysis Handbook IV. Athens, GA: Micro-Macro Publishing.

Cherney, J. H., and E. Small. 2016. "Industrial Hemp in North America: Production, Politics, and Potential." Agronomy 6 (4): 58. 10.3390/agronomy6040058.

Deng, G., G. Du, Y. Yang, Y. Bao, and F. Liu. 2019. “Planting Density and Fertilization Evidently Influence the Fiber Yield of Hemp (Cannabis sativa L.)." Agronomy 9 (7): 1-10. https://doi.org/10.3390/agronomy9070368.

Finnan, J., and B. Burke. 2013. "Potassium Fertilization of Hemp (Cannabis sativa)." Industrial Crops \& Products 41:419-422. https://doi.org/10.1016/j.indcrop.2012.04.055.

Heard, J., K. Watson, and J. Kostiuk. 2007. "Nutrient Uptake and Partitioning by Industrial Hemp." Manitoba Agronomists Conference Proceedings 2007. http://www. umanitoba.ca/faculties/afs/MAC_proceedings/proceedings/2007/Heard_poster.pdf (accessed June 14, 2020).

Mylavarapu, R. S. 2010. "Diagnostic Nutrient Testing." HortTech. 20:19-22.

Mylavarapu, R. S., D. Wright, and G. Kidder. 2015. UF/IFAS Standardized Fertilization Recommendations for Agronomic Crops. SL129. Gainesville: University of Florida Institute of Food and Agricultural Sciences. https://edis.ifas.ufl.edu/ ss163.

Ontario Ministry of Agriculture. 2016. "Growing Industrial Hemp in Ontario." http://www.omafra.gov.on.ca/english/ crops/facts/00-067.htm\#fertility. 
Roth, G., J. Harper, H. Manzo, A. Collins, and L. Kime.

2018. "Industrial Hemp Production." Penn State Extension. https://extension.psu.edu/industrial-hemp-production.

Struik, P. C., S. Amaducci, M. J. Bullard, N. C. Stutterheim, G. Venturi, and H. T. H. Cromack. 2000. "Agronomy of Fibre Hemp (Cannabis sativa L.) in Europe." Industrial Crops and Products 11 (2-3): 107-118. https://doi.org/10.1016/ S0926-6690(99)00048-5.

Vera, C. L., S. S. Malhi, S. M. Phelps, W. E. May, and E. N. Johnson. 2010. "N, P, and S Fertilization Effects on Industrial Hemp in Saskatchewan." Canadian Journal of Plant Science 90 (2): 179-184. https://doi.org/10.4141/CJPS09101. 